\title{
HSV-1 strain McKrae is more neuroinvasive than HSV-1 KOS after corneal or vaginal inoculation in mice
}

\author{
Hong Wanga ${ }^{a}$ David J. Davidob, and Lynda A. Morrison ${ }^{a}{ }^{*}$ \\ aDepartment of Molecular Microbiology and Immunology, Saint Louis University School of \\ Medicine, St. Louis, MO 63104, USA \\ bDepartment of Molecular Biosciences, University of Kansas, Lawrence, KS 66045, USA
}

\section{Abstract}

Strains of HSV-1 have been noted to vary in their pathogenesis. We compared the replication of strains KOS and McKrae in mice by two routes of infection, ocular and vaginal. Peripheral replication of KOS was similar (cornea) or attenuated over time (vagina) compared with McKrae; however, McKrae replicated in the nervous system to significantly higher levels than KOS after inoculation by either route. Host genetic background strongly influenced the capacity for virus entry into the nervous system from the vagina. KOS and McKrae replicated equivalently after intracranial inoculation, indicating that McKrae's pathogenic phenotype is linked to neuroinvasiveness rather than neurovirulence.

\section{Keywords}

herpes simplex virus; pathogenesis; cornea; vagina; central nervous system; mice

\begin{abstract}
Herpes simplex virus 1 (HSV-1) is a herpesvirus belonging to the neurotropic Alphaherpesvirinae subfamily (Roizman et al., 2012). HSV-1 infections can be asymptomatic or cause cold sores, corneal ulcerations, and rare but life-threatening encephalitis (Roizman et al., 2012). In addition, HSV-1 causes a growing proportion of HSV genital infections (Bhattarakosol et al., 2005; Gilbert et al., 2011; Horowitz et al., 2011; Kortekangas-Savolainen and Vuorinen, 2007; Pena et al., 2010; Pereira et al., 2012; Smith and Roberts, 2009) which also can be asymptomatic, result in painful ulcerative lesions, or sometimes cause aseptic meningitis or autonomic dysfunction (Gupta et al., 2007). Initial HSV-1 infections at mucosal surfaces rapidly spread into sensory neurons, where the virus remains latent until it receives a reactivation stimulus. Numerous strains of HSV-1 have been isolated that vary in their virulence (Bergstrom et al., 1990; Dix et al., 1983; Hill et al., 1987). One HSV-1 strain, KOS (Smith, 1964), was originally isolated from a cold sore and has been passaged 12 times in tissue culture. KOS is frequently used to investigate HSV-1 gene function and pathogenesis (Schaffer et al., 1973), and has been described as less virulent than a number of other HSV-1 strains (Luker et al., 2006; Perng et al., 2002; Strelow and Leib, 1995). Another HSV-1 strain, McKrae, was isolated from a patient with herpes simplex keratitis (Williams et al., 1965), and passaged an unknown number of times
\end{abstract}

() 2013 Elsevier B.V. All rights reserved.

Tel.: +00-1-314-977-8874; fax: +00-1-314-977-8717, morrisla@ slu.edu.

Publisher's Disclaimer: This is a PDF file of an unedited manuscript that has been accepted for publication. As a service to our customers we are providing this early version of the manuscript. The manuscript will undergo copyediting, typesetting, and review of the resulting proof before it is published in its final citable form. Please note that during the production process errors may be discovered which could affect the content, and all legal disclaimers that apply to the journal pertain. 
in tissue culture. McKrae undergoes spontaneous or induced reactivation at a higher frequency and is among the most virulent HSV-1 strains in animal models (Hill et al., 1987; Perng et al., 2002; Sawtell et al., 1998; Strelow et al., 1994).

Inter-strain differences in HSV-1 peripheral replication and virulence have been observed in animal models. HSV-1 strain KOS replicates as well as or better than strain 17 syn+ or McKrae in the snout or cornea of mice (Sawtell et al., 1998; Strelow et al., 1994), although bioluminescence imaging indicates KOS is attenuated relative to 17syn+ and McKrae over time after inoculation in these sites (Luker et al., 2006). After injection into the footpad or anterior chamber, KOS reaches the nervous system similarly to 17syn+ or H129, respectively, but is dramatically reduced in its capacity to disseminate in neural tissue (Thompson et al., 1986; Archin and Atherton, 2002) and to cause lethal infection after intracranial (i.c.) inoculation compared with other strains (Dix et al., 1983). HSV-1 strain McKrae, in contrast to KOS, is highly virulent following corneal inoculation of rabbits and mice (Perng et al., 1995). KOS and McKrae appear to replicate efficiently in the mucosa after intravaginal (i.vag.) inoculation in some studies (Inagaki-Ohara et al., 2000; Zheng et al. 2012) but not others (Murphy et al., 2003), and neither appears to reach the nervous system (Inagaki-Ohara et al., 2000; Zheng et al., 2012). However, a direct comparison of these two HSV-1 strains by the genital route has not been reported. In one study comparing i.vag. inoculation of HSV-1 strain 17syn+ to strain IES, a thymidine kinase-deficient mutant (Muller et al., 1979), 17syn+ replicated for a prolonged period in the genital mucosa, caused severe vaginitis, and spread more readily to the nervous system (Podlech et al., 1996). Taken together, these observations suggest strain- and route-dependent differences in HSV-1 neuroinvasiveness.

To directly test strain-dependent differences in pathogenesis during acute infection, we compared the capacity of HSV-1 strains KOS and McKrae to replicate and spread in mice after inoculation by two routes relevant to human infection, the cornea and the genital tract. After inoculation of C57BL/6 (B6) mice via the cornea as previously described (Morrison and Knipe, 1994), KOS and McKrae replicated to a similar extent in the corneal epithelium through $4 \mathrm{~d}$ post-infection (Fig. 1A). Subsequently, KOS replicated to nearly the same extent as McKrae in the trigeminal ganglia; however, KOS titers in the brainstem and brain were reduced 100-fold compared with McKrae (Fig. 1B). To determine the effect of host genetic background on KOS attenuation, we repeated the experiment in BALB.B mice which share the MHC locus of B6 mice but diverge with regard to non MHC-linked genes. KOS replicated as well as or slightly better than McKrae over time in the corneal epithelium of BALB.B mice (Fig. 1C), but again was markedly attenuated for replication in the nervous system (Fig. 1D).

To distinguish whether the persistent neural attenuation of KOS reflects a reduced capacity to spread into the central nervous system (CNS) or to replicate in neural tissue, mice were infected i.c. with strains KOS or McKrae as previously described (Korom et al., 2008). Replication of KOS and McKrae was equivalent in B6 (Fig. 2A) and BALB.B (Fig. 2B) mice at $24 \mathrm{~h}$ post-infection, and both viruses replicated to higher titers in BALB.B mice than B6 mice. To ensure that virus titers had not simply reached their maximum, we also examined titers of the viruses $48 \mathrm{~h}$ post-infection. Both strains showed a similar increase in titer at $48 \mathrm{~h}$. These data suggest that the attenuation of KOS after corneal inoculation represents a defect in neuroinvasiveness rather than in growth in neural tissue.

We also infected mice i.vag. as previously described (Morrison et al., 1998) with KOS and McKrae. In B6 mice, KOS and McKrae replicated to similar extents in the vaginal mucosa (Fig. 3A), except for a transient spike in the day 4 titers of McKrae-infected mice. Only McKrae, however, caused significant inflammation of the external genitalia (Fig. 3B), and 
weight loss (data not shown). KOS was not detected in neural tissue and McKrae was detected only in rare instances (Fig. 3C). In BALB.B mice, KOS and McKrae replicated to nearly the same extent in the vaginal mucosa over the first $2 \mathrm{~d}$ post-infection (Fig. 3D). From 3 to $5 \mathrm{~d}$ post-infection, however, the titer of KOS fell to an undetectable level, while replication of McKrae declined more slowly. McKrae also provoked genital inflammation which steadily grew more severe (Fig. 3E). In contrast, mice infected i.vag. with KOS showed no signs of genital disease. Body weight of McKrae-infected mice also declined an average of $15 \%$ by $7 \mathrm{~d}$ post-infection, whereas mice infected with KOS gained weight (data not shown). McKrae replicated robustly in spinal cord, brainstem, and brain of BALB.B mice, but KOS was below the level of detection in nearly all cases (Fig. 3F). Thus, McKrae caused peripheral disease and spread to the CNS of mice after i.vag. inoculation much more readily than KOS.

HSV-1 strains KOS and McKrae are examples of strains with low and high reactivation potential, respectively, in animal models of ocular infection (Berman and Hill, 1985; Gerdes and Smith, 1983; Gordon et al., 1990; Hill et al., 1987; Laycock et al., 1991; Sawtell et al., 1998; Shimeld et al., 1990; Strelow et al., 1994; Willey et al., 1984). Here we demonstrate by direct in vivo comparison that HSV-1 strains KOS and McKrae also differ in neuroinvasiveness or capacity to spread into the CNS after ocular or vaginal infection of mice. The differences in replication capacity in vivo were not reproduced in primary mouse fibroblast, brainstem astrocyte, or brainstem neuron cultures (data not shown), suggesting factors in the intact host restrict KOS replication and spread. Importantly, because B6 and BALB.B mice share the same H-2 haplotype, the greater attenuation of KOS compared with McKrae that we observed in B6 mice indicates a non MHC-linked host resistance mechanism.

Replication of McKrae resembled that of KOS in the vaginal mucosa of B6 mice, except for a transient upturn on day 4 post-infection, which is typically observed with virulent strains in the i.vag. model (Thebeau et al., 2007; Morrison 2008; Vagvala et al., 2009). This increase may result from virus infection of newly regenerated vaginal epithelial cells, or virus returning from the dorsal root ganglia to the mucosa and amplifying the infection. Further investigation will be needed to distinguish between these possibilities. We made the novel observation that KOS replication is comparatively restricted in the vaginal mucosa of BALB.B mice, primarily after day 2 post-infection. This attenuation may represent differential sensitivity of KOS to type I IFNs (Murphy et al., 2003) or substance P (Svensson et al., 2005) but is more likely related to innate cellular immune responses such as neutrophils or NK T cells (Milligan et al., 2001; Ashkar and Rosenthal, 2003). Conceivably, HSV-1 strain-dependent differences in chemokine production could elicit different types or amount of inflammatory cell infiltrates in the mouse genital tract (Zheng et al., 2012).

Reduced capacity of KOS to counteract TLR2 or type I IFN signaling in the CNS (KurtJones et al., 2004; Wang et al., 2012) could also possibly play a role in its relative neural attenuation.

Two lines of evidence from our study demonstrate that KOS has a defect in neuroinvasiveness and/or neural spread rather than neurovirulence. First, KOS replicated to a similar extent as McKrae after direct i.c. inoculation, indicating KOS has no inherent defect for growth in the CNS; however, KOS was not detected in the nervous system of most mice after i.vag. inoculation. Second, although KOS and McKrae replicated in the cornea and spread from the cornea to the TG with approximately equal efficiency in B6 mice, McKrae spread from the TG to the CNS more aggressively than KOS. Our results using the corneal and vaginal routes of infection, combined with previous results of footpad inoculation (Dix et al., 1983; Thompson et al., 1986) suggest a universal deficit in KOS neuroinvasiveness. Whether HSV-1 KOS enters the nervous system at a high frequency but 
does not replicate efficiently will be a subject of future investigation. Neuronal entry and spread are determined in part by gE/gI (Dingwell et al., 1995), but many viral gene products have been described as neurovirulence or pathogenic factors and may have a role in promoting replication in neurons. The viral determinants that contribute to McKrae's in vivo phenotypes are largely unknown. One study comparing wildtype McKrae to a gK mutant suggested a potential role for $\mathrm{gK}$ in neuroinvasiveness (David et al., 2008); however, a profound reduction in corneal spread observed with this mutant complicated the interpretation. Additional studies comparing a wild-type HSV-1 strain to gB, ICP34,5, or uracil DNA glycosylase in vivo (Bergstrom et al, 1992; Bower et al., 1999; Pyles and Thompson, 1994), suggest roles for these gene products in neuroinvasion, Sequence analyses of the KOS and McKrae genomes (Macdonald et al. 2012a; Macdonald et al. 2012b; Watson et al., 2012) indicate non-synonymous variations in these genes and many others, some of which are expected to delineate the molecular basis for differences in the pathogenicity of these two HSV-1 strains.

\section{Acknowledgments}

We thank Allie Taniuchi for technical assistance. This work was supported in part by institutional funds to L.A.M. and by National Institutes of Health grant R01AI72357 to D.J.D.

\section{References}

Archin NM, Atherton SS. Rapid spread of a neurovirulent strain of HSV-1 through the CNS of BALB/ c mice following anterior chamber inoculation. J Neurovirol. 2002; 8:122-135. [PubMed: 11935464]

Ashkar AA, Rosenthal KL. Interleukin-15 and natural killer and NKT cells play a critical role in innate protection against genital herpes simplex virus type 2 infection. J Virol. 2003; 77:10168-10171. [PubMed: 12941930]

Berman EJ, Hill JM. Spontaneous ocular shedding of HSV-1 in latently infected rabbits. Invest Ophthalmol Vis Sci. 1985; 26:587-590. [PubMed: 2984140]

Bergstrom T, Alestig K, Svennerholm B, Horal P, Skoldenberg B, Vahlne A. Neurovirulence of herpes simplex virus types 1 and 2 isolates in diseases of the central nervous system. Eur J Clin Microbiol Infect Dis. 1990; 9:751-757. [PubMed: 2175706]

Bergström T, Sjögren-Jansson E, Jeansson S, Lycke E. Mapping neuroinvasiveness of the herpes simplex virus type 1 encephalitis-inducing strain 2762 by the use of monoclonal antibodies. Mol Cell Probes. 1992; 6:41-49. [PubMed: 1312221]

Bhattarakosol P, Visaprom S, Sangdara A, Mungmee V. Increase of genital HSV-1 and mixed HSV-1 and HSV-2 infection in Bangkok, Thailand. J Med Assoc Thai. 2005; 88(Suppl 4):S300-S304. [PubMed: 16623045]

Bower JR, Mao H, Durishin C, Rozenbom E, Detwiler M, Rempinski D, Karban TL, Rosenthal KS. Intrastrain variants of herpes simplex virus type 1 isolated from a neonate with fatal disseminated infection differ in the ICP34.5 gene, glycoprotein processing, and neuroinvasiveness. J Virol. 1999; 73:3843-3853. [PubMed: 10196279]

David AT, Baghian A, Foster TP, Chouljenko VN, Kousoulas KG. The herpes simplex virus type 1 (HSV-1) glycoprotein $\mathrm{K}(\mathrm{gK})$ is essential for viral corneal spread and neuroinvasiveness. Curr Eye Res. 2008; 33:455-467. [PubMed: 18568883]

Dingwell KS, Doering LC, Johnson DC. Glycoproteins E and I facilitate neuron-to-neuron spread of herpes simplex virus. J Virol. 1995; 69:7087-7098. [PubMed: 7474128]

Dix RD, McKendall RR, Baringer JR. Comparative neurovirulence of herpes simplex virus type 1 strains after peripheral or intracerebral inoculation of BALB/c mice. Infect Immun. 1983; 40:103112. [PubMed: 6299955]

Gerdes JC, Smith DS. Recurrence phenotypes and establishment of latency following rabbit keratitis produced by multiple herpes simplex virus strains. J Gen Virol. 1983; 64:2441-2454. [PubMed: 6315865] 
Gilbert M, Li X, Petric M, Krajden M, Isaac-Renton JL, Ogilvie G, Rekart ML. Using centralized laboratory data to monitor trends in herpes simplex virus type 1 and 2 infection in British Columbia and the changing etiology of genital herpes. Can J Public Health. 2011; 102:225-229. [PubMed: 21714324]

Gordon YJ, McKnight JL, Ostrove JM, Romanowski E, Araullo-Cruz T. Host species and strain differences affect the ability of an HSV-1 ICP0 deletion mutant to establish latency and spontaneously reactivate in vivo. Virology. 1990; 178:469-477. [PubMed: 2171191]

Gupta R, Warren T, Wald A. Genital herpes. Lancet. 2007; 370:2127-2137. [PubMed: 18156035]

Hill JM, Rayfield MA, Haruta Y. Strain specificity of spontaneous and adrenergically induced HSV-1 ocular reactivation in latently infected rabbits. Curr Eye Res. 1987; 6:91-97. [PubMed: 3030660]

Horowitz R, Aierstuck S, Williams EA, Melby B. Herpes simplex virus infection in a university health population: clinical manifestations, epidemiology, and implications. J Am Coll Health. 2011; 59:69-74. [PubMed: 20864431]

Inagaki-Ohara K, Daikoku T, Goshima F, Nishiyama Y. Impaired induction of protective immunity by highly virulent herpes simplex virus type 2 in a murine model of genital herpes. Arch Virol. 2000; 145:1989-2002. [PubMed: 11087087]

Korom M, Wylie KM, Morrison LA. Selective ablation of virion host shutoff protein RNase activity attenuates herpes simplex virus 2 in mice. J Virol. 2008; 82:3642-3653. [PubMed: 18234805]

Kortekangas-Savolainen O, Vuorinen T. Trends in herpes simplex virus type 1 and 2 infections among patients diagnosed with genital herpes in a Finnish sexually transmitted disease clinic, 1994-2002. Sex Transm Dis. 2007; 34:37-40. [PubMed: 17195754]

Kurt-Jones EA, Chan M, Zhou S, Wang J, Reed G, Bronson R, Arnold M, Knipe DM, Finberg RW. Herpes simplex virus 1 interaction with Toll-like receptor 2 contributes to lethal encephalitis. Proc Natl Acad Sci USA. 2004; 101:1315-1320. [PubMed: 14739339]

Laycock KA, Lee SF, Brady RH, Pepose JS. Characterization of a murine model of recurrent herpes simplex viral keratitis induced by ultraviolet B radiation. Invest Ophthalmol Vis Sci. 1991; 32:2741-2746. [PubMed: 1654309]

Luker KE, Schultz T, Romine J, Leib DA, Luker GD. Transgenic reporter mouse for bioluminescence imaging of herpes simplex virus 1 infection in living mice. Virology. 2006; 347:286-295. [PubMed: 16430938]

Macdonald SJ, Mostafa HH, Morrison LA, Davido DJ. Genome sequence of herpes simplex virus 1 strain KOS. J Virol. 2012a; 86:6371-6372. [PubMed: 22570244]

Macdonald SJ, Mostafa HH, Morrison LA, Davido DJ. Genome sequence of herpes simplex virus 1 strain McKrae. J Virol. 2012b; 86:9540-9541. [PubMed: 22879612]

Milligan GN, Bourne N, Dudley KL. Role of polymorphonuclear leukocytes in resolution of HSV-2 infection of the mouse vagina. J Reprod Immunol. 2001; 49:49-65. [PubMed: 11137112]

Morrison LA. Replication-defective virus vaccine-induced protection of mice from genital herpes simplex virus 2 requires CD4 T cells. Virology. 2008; 376:205-210. [PubMed: 18410949]

Morrison LA, Da Costa XJ, Knipe DM. Influence of mucosal and parenteral immunization with a replication-defective mutant of HSV-2 on immune responses and protection from genital challenge. Virology. 1998; 243:178-187. [PubMed: 9527927]

Morrison LA, Knipe DM. Immunization with replication-defective mutants of herpes simplex virus type 1: Sites of immune intervention in pathogenesis of challenge virus infection. J Virol. 1994; 68:689-696. [PubMed: 8289372]

Müller WE, Zahn RK, Arendes F, Falke D. Phosphorylation of arabinofuranosylthymine in noninfected and herpesvirus (TK+ and TK-)-infected cells. J Gen Virol. 1979; 43:261-271. [PubMed: 225422]

Murphy JA, Duerst RJ, Smith TJ, Morrison LA. Herpes simplex virus type 2 virion host shutoff protein regulates alpha/beta interferon but not adaptive immune responses during primary infection in vivo. J Virol. 2003; 77:9337-9345. [PubMed: 12915549]

Pena KC, Adelson ME, Mordechai E, Blaho JA. Genital herpes simplex virus type 1 in women: detection in cervicovaginal specimens from gynecological practices in the United States. J Clin Microbiol. 2010; 48:150-153. [PubMed: 19923487] 
Pereira VS, Moizeis RN, Fernandes TA, Araujo JM, Meissner RV, Fernandes JV. Herpes simplex virus type 1 is the main cause of genital herpes in women of Natal, Brazil. Eur J Obstet Gynecol Reprod Biol. 2012; 161:190-193. [PubMed: 22424592]

Perng GC, Mott KR, Osorio N, Yukht A, Salina S, Nguyen QH, Nesburn AB, Wechsler SL. Herpes simplex virus type 1 mutants containing the KOS strain ICP34.5 gene in place of the McKrae ICP34.5 gene have McKrae-like spontaneous reactivation but non-McKrae-like virulence. J Gen Virol. 2002; 83:2933-2942. [PubMed: 12466469]

Perng GC, Thompson RL, Sawtell NM, Taylor WE, Slanina SM, Ghiasi H, Kaiwar R, Nesburn AB, Wechsler SL. An avirulent ICP34.5 deletion mutant of herpes simplex virus type 1 is capable of in vivo spontaneous reactivation. J Virol. 1995; 69:3033-3041. [PubMed: 7707530]

Podlech J, Hengerer F, Fleck M, Eray K, Falke D. Asymptomatic vaginal herpes simplex virus infections in mice: virology and pathohistology. Arch Virol. 1996; 141:263-274. [PubMed: 8634019]

Pyles RB, Thompson RL. Evidence that the herpes simplex virus type 1 uracil DNA glycosylase is required for efficient viral replication and latency in the murine nervous system. J Virol. 1994; 68:4963-4972. [PubMed: 8035495]

Roizman, B.; Knipe, DM.; Whitley, RJ. Herpes simplex viruses. In: Knipe, DM., et al., editors. Field's Virology. 5. Lippincott, Williams, and Wilkins; New York: 2007. p. 2501-2601.

Sawtell NM, Poon DK, Tansky CS, Thompson RL. The latent herpes simplex virus type 1 genome copy number in individual neurons is virus strain specific and correlates with reactivation. $\mathrm{J}$ Virol. 1998; 72:5343-5350. [PubMed: 9620987]

Schaffer PA, Aron GM, Biswal N, Benyesh-Melnick M. Temperature-sensitive mutants of herpes simplex virus type 1: isolation, complementation and partial characterization. Virology. 1973; 52:57-71. [PubMed: 4372782]

Shimeld C, Hill TJ, Blyth WA, Easty DL. Reactivation of latent infection and induction of recurrent herpetic eye disease in mice. J Gen Virol. 1990; 71:397-404. [PubMed: 2155293]

Smith KO. Relationship between the envelope and the infectivity of herpes simplex virus. Proc Soc Exp Biol Med. 1964; 115:814-816. [PubMed: 14155835]

Smith PD, Roberts CM. American College Health Association annual Pap test and sexually transmitted infection survey: 2006. J Am Coll Health. 2009; 57:389-394. [PubMed: 19114378]

Strelow LI, Laycock KA, Jun PY, Rader KA, Brady RH, Miller JK, Pepose JS, Leib DA. A structural and functional comparison of the latency-associated transcript promoters of herpes simplex virus type 1 strains KOS and McKrae. J Gen Virol. 1994; 75:2475-2480. [PubMed: 8077951]

Strelow LI, Leib DA. Role of the viron host shutoff (vhs) of herpes simplex virus type 1 in latency and pathogenesis. J Virol. 1995; 69:6779-6786. [PubMed: 7474089]

Svensson A, Kaim J, Mallard C, Olsson A, Brodin E, Hokfelt T, Eriksson K. Neurokinin 1 receptor signaling affects the local innate immune defense against genital herpes virus infection. $\mathrm{J}$ Immunol. 2005; 175:6802-6811. [PubMed: 16272337]

Thebeau LG, Vagvala SP, Wong YM, Morrison LA. B7 costimulation molecules expressed from the herpes simplex virus 2 genome rescue immune induction in B7-deficient mice. J Virol. 2007; 81:12200-12209. [PubMed: 17804511]

Thompson RL, Cook ML, Devi-Rao GB, Wagner EK, Stevens JG. Functional and molecular analyses of the avirulent wild-type herpes simplex virus type 1 strain KOS. J Virol. 1986; 58:203-211. [PubMed: 3005649]

Vagvala SP, Thebeau LG, Wilson SR, Morrison LA. Virus-encoded B7-2 costimulation molecules enhance the protective capacity of a replication-defective herpes simplex virus type 2 vaccine in immunocompetent mice. J Virol. 2009; 83:953-960. [PubMed: 18987142]

Wang JP, Bowen GN, Zhou S, Cerny A, Zacharia A, Knipe DM, Finberg RW, Kurt-Jones EA. Role of specific innate immune responses in herpes simplex virus infection of the central nervous system. J Virol. 2012; 86:2273-2281. [PubMed: 22171256]

Watson G, Xu W, Reed A, Babra B, Putman T, Wick E, Wechsler SL, Rohrmann GF, Jin L. Sequence and comparative analysis of the genome of HSV-1 strain McKrae. Virology. 2012; 433:528-537. [PubMed: 23021301] 
Willey DE, Trousdale MD, Nesburn AB. Reactivation of murine latent HSV infection by epinephrine iontophoresis. Invest Ophthalmol Vis Sci. 1984; 25:945-950. [PubMed: 6086546]

Williams LE, Nesburn AB, Kaufman HE. Experimental induction of disciform keratitis. Arch Ophthalmol. 1965; 73:112-114. [PubMed: 14223669]

Zheng M, Conrady CD, Ward JM, Bryant-Hudson KM, Carr DJ. Comparison of the host immune response to herpes simplex virus 1 (HSV-1) and HSV-2 at two different mucosal sites. J Virol. 2012; 86:7454-7458. [PubMed: 22532684] 
B6 Mice
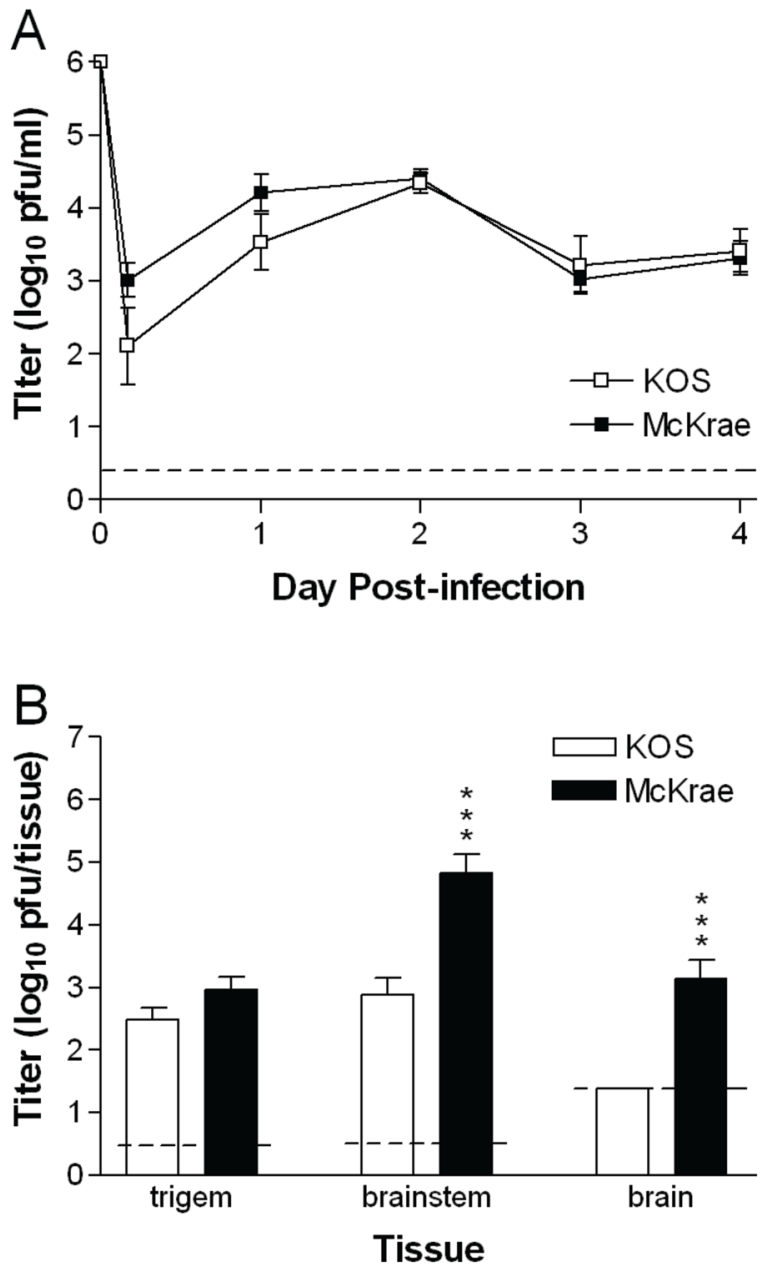

BALB.B Mice
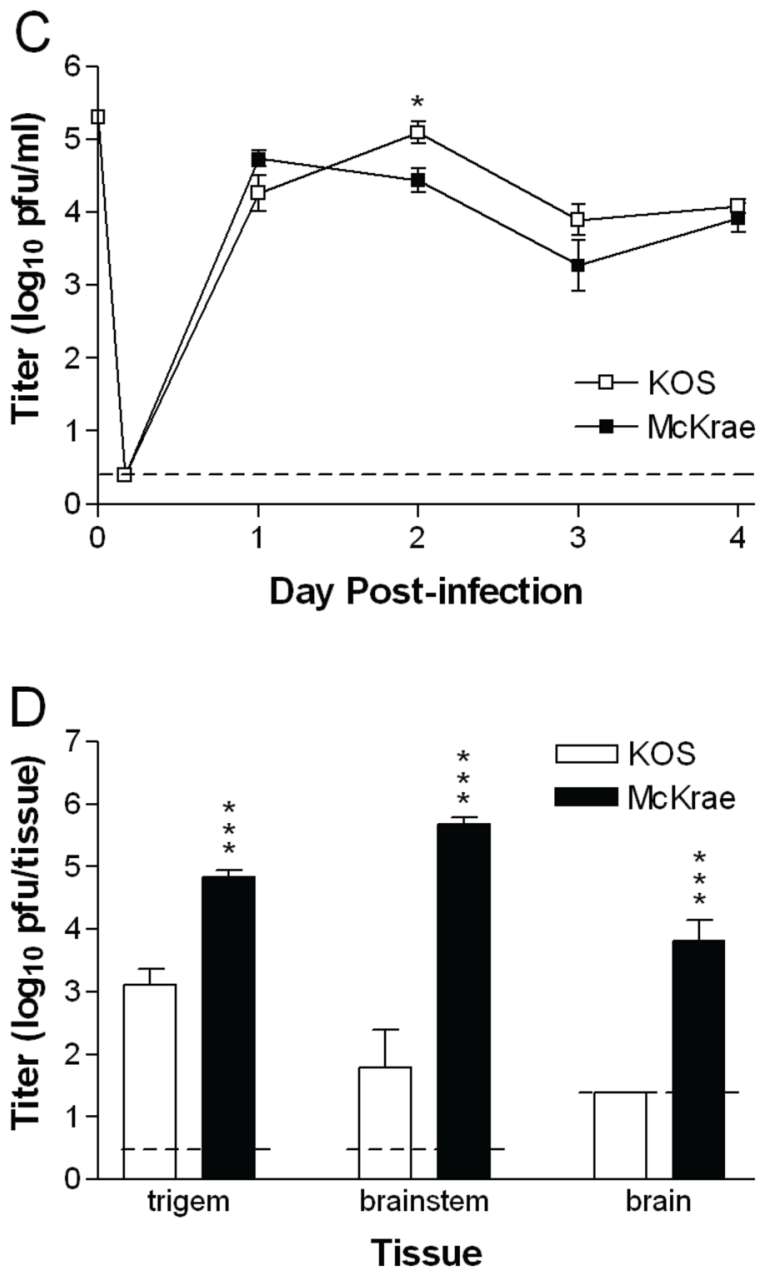

Fig. 1.

Corneal infection with HSV-1 McKrae results in higher titers in the nervous system than HSV-1 KOS. KOS or McKrae was inoculated onto the scarified corneas of (A and B) B6 mice at $1 \times 10^{6}$ pfu per eye, or (C and D) BALB.B mice at $2 \times 10^{5}$ pfu/eye. (A and C) Titer of virus shed in tear film over time post-infection. (B and D) Titer of virus in nervous system tissues was determined $5 \mathrm{~d}$ (B6) or $4 \mathrm{~d}$ (BALB.B) post-infection. Values are the geometric means \pm SEM of 5 to 6 mice per group (B6) or 7 mice per group (BALB.B) and are the combined results of two independent experiments for each mouse strain. Dashed lines represent limit of detection in the assay. *, $\mathrm{P}=0.0125$; ***, $\mathrm{P}=0.0006$ to $<0.0001$. 


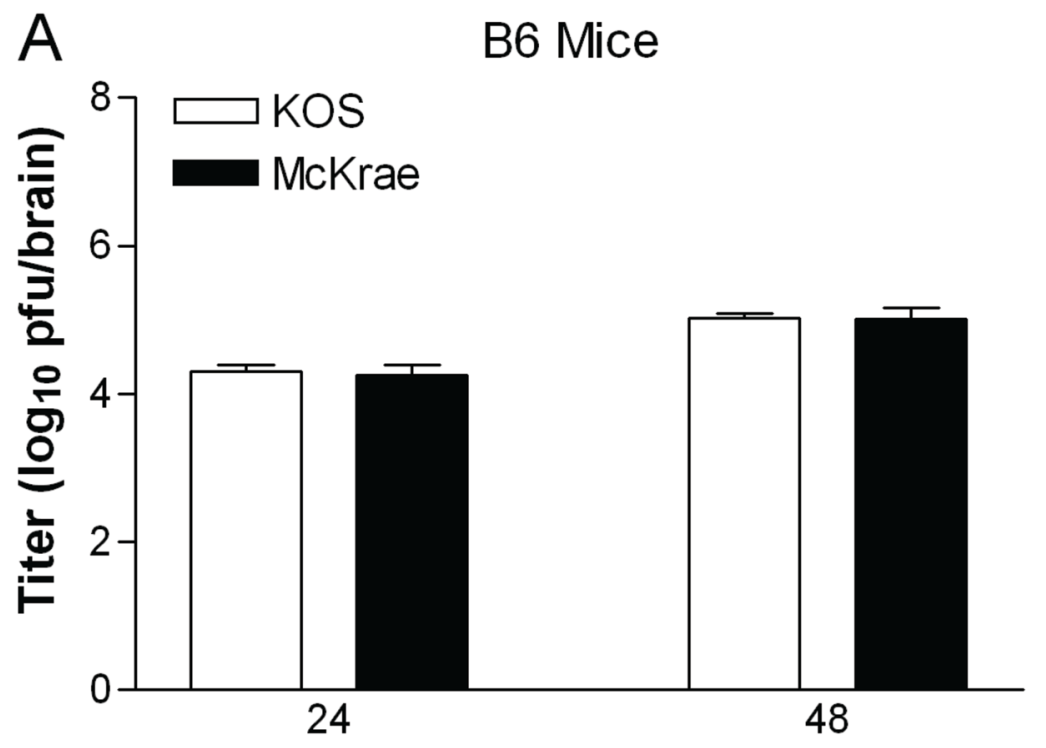

\section{Hours Post-infection}

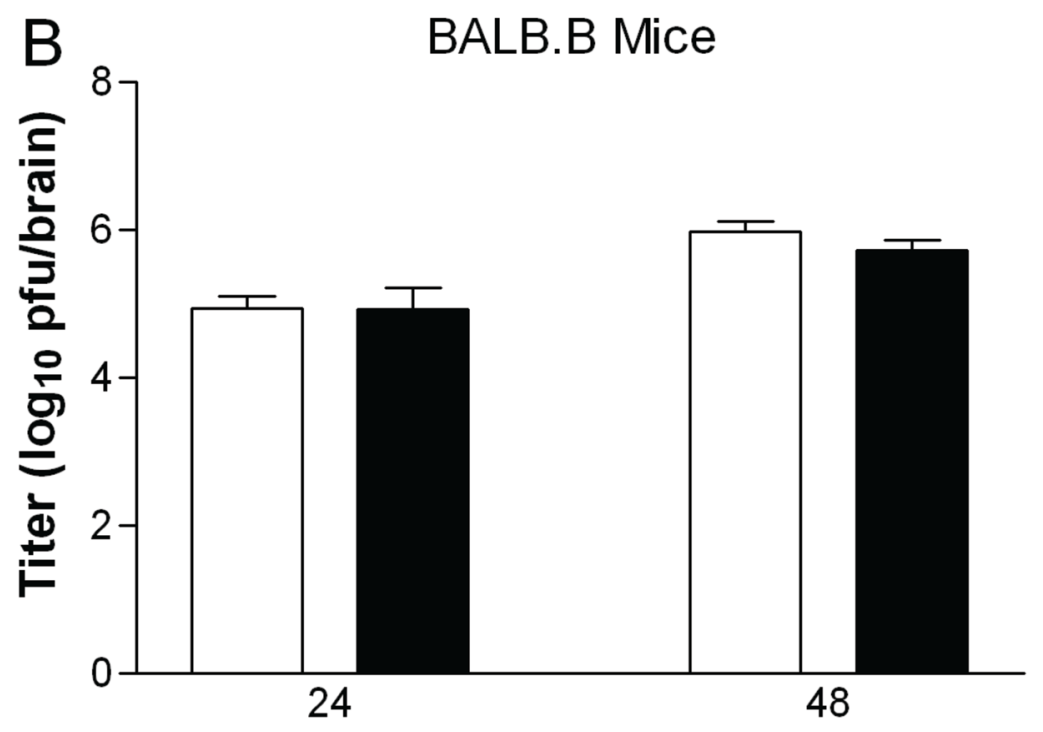

Hours Post-infection

Fig. 2.

Intracranial inoculation yields equivalent titers of HSV-1 KOS and McKrae. Groups of 5 to 7 mice were inoculated i.c. with $1 \times 10^{3}$ pfu of virus. Values are the geometric mean titers \pm SEM of virus detected in brain tissue of (A) B6 mice and (B) BALB.B mice $24 \mathrm{~h}$ and $48 \mathrm{~h}$ after infection, and are the combined results of two independent experiments each. The increase from 24 to $48 \mathrm{~h}$ was statistically significant $(\mathrm{P}=0.0265$ to 0.0001$)$. 
B6 Mice

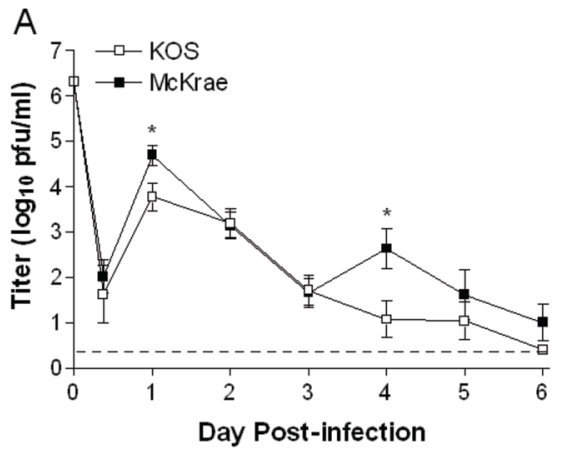

$\mathrm{B}$
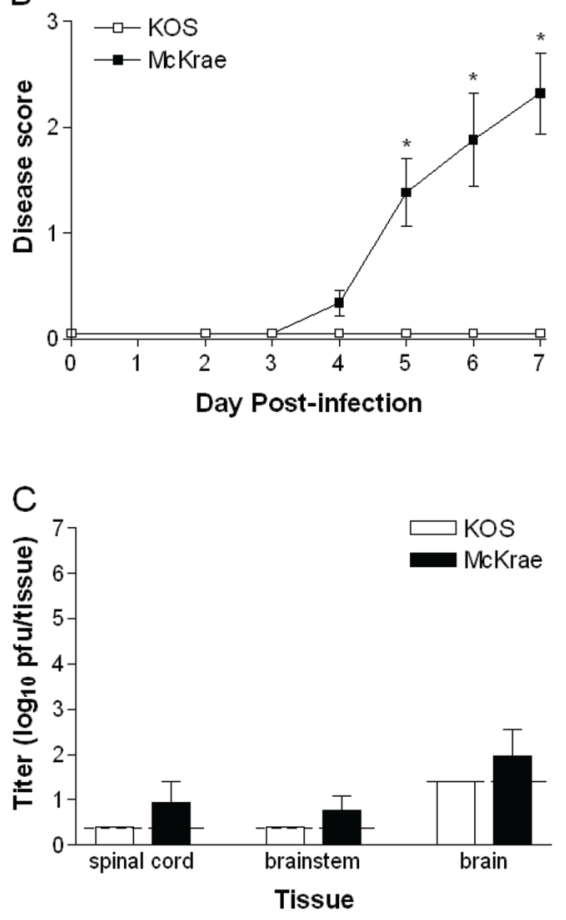

BALB.B Mice

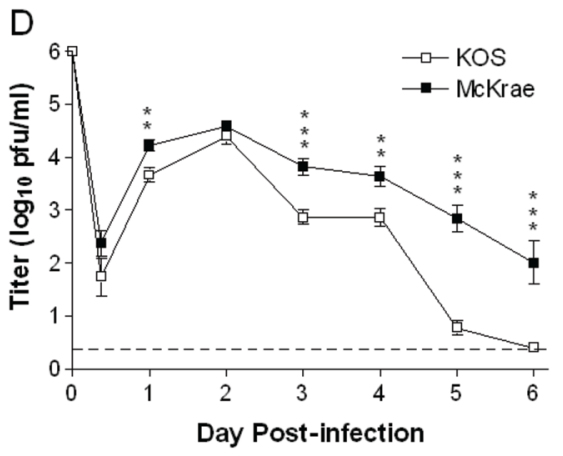

$\mathrm{E}$
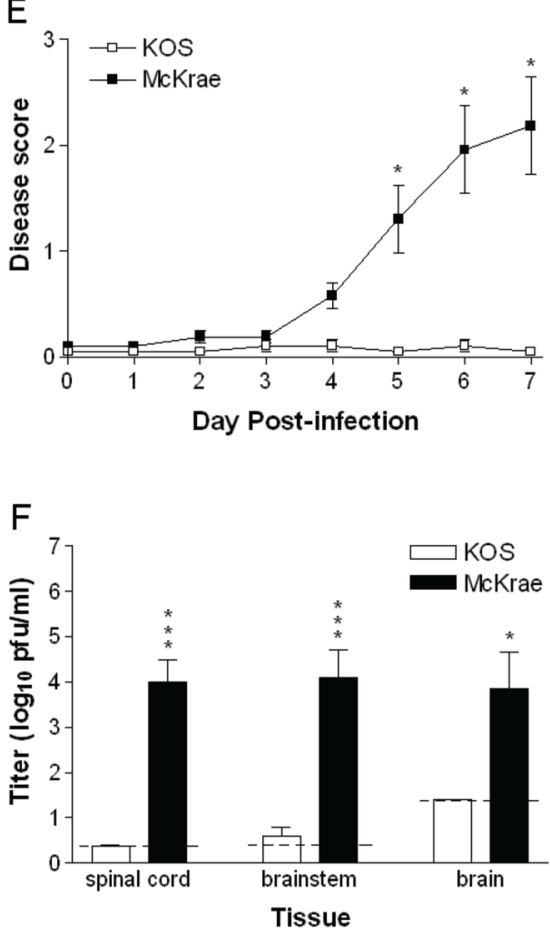

Fig. 3.

HSV-1 McKrae is more virulent than KOS after intravaginal infection. KOS or McKrae was inoculated i.vag. into (A-C) B6 mice at $2 \times 10^{6}$ pfu per mouse, or (D-F) BALB.B mice at $1 \times 10^{6} \mathrm{pfu} / \mathrm{mouse}$. (A and D) Titer of virus shed from the vaginal mucosa over time postinfection. (B and E) Genital disease scores, determined in masked fashion based on the scale 0 , normal; 1 slight erythema and edema; 2 marked erythema and edema; 3 , presence of lesions. ( $\mathrm{C}$ and $\mathrm{F}$ ) Titer of virus in nervous system tissues $7 \mathrm{~d}$ post-infection. Values are the geometric mean + SEM of 7 to 8 B6 or BALB.B mice per group and are the combined results of two independent experiments. Dashed lines represent limit of detection in the assay. *, $\mathrm{P}=0.031$ to 0.0112 ; **, $\mathrm{P}=0.0052$ to $0.004 ; * * *, \mathrm{P}=0.0002$ to $<0.0001$. 